\title{
Jurist-Diction
}

Volume 1 No. 1, September 2018

Article history: Submitted 2 August 2018; Accepted 15 August 2018; Available online 3 September 2018

\section{PENGUATAN KETERWAKILAN PEREMPUAN DALAM KEPENGURUSAN PARTAI POLITIK}

\author{
Isyrofah Amaliyah Achmad \\ afahhwi@gmail.com \\ Universitas Airlangga
}

\begin{abstract}
Political parties provide a chance for people to express their political aspirations, freedom and furthering democratic openness. However, in pursuing these ends through such a vessel, the fulfilment of rights face some challenges including the recognitions of women's rights in relation to their representation in political organizations and movements. This has triggered a push from certain groups for increasing female representation in parliament, increasing women's political participation, and enhancing women's leadership in the policy-making. Awareness of women's role in politics began to be built through the rules of affirmative action as outlined in the law of general election necessitating a minimum number of 30 percent women's representation to be achieved. Affirmative action is not new, since the enactment of Law Number 12 Year 2003 regarding General Election until the coming into effect of the new law, Law Number 7 Year 2017 regarding General Election raises the pros and cons. Article 173 paragraph (2) (e) requires 30 percent of the representation of women as active parts of political party leadership as one of the mandatory requirements to become a participant in the 2019 general election. Through Law No. 7 of 2017, it is expected that women representation reach up to 30 percent through strengthening the management of political parties at the central level.
\end{abstract}

Keywords: Political Party; women's rights; women's political participation; affirmative acti; Law of Republic of Indonesia number 7 year 2017 concerning general election.

\begin{abstract}
Abstrak
Partai politik merupakan ruang bagi masyarakat untuk mengekspresikan kebebasan dan keterbukaan berdemokrasi. Di samping hal tersebut, pemenuhan hak-hak juga mengalami berbagai tantangan termasuk untuk mewujudkan hak perempuan yang terkait dengan hak keterwakilan perempuan dalam kepengurusan partai politik, representasi perempuan di parlemen, peningkatan partisipasi politik perempuan, hingga peningkatan kepemimpinan perempuan dalam pengambil kebijakan. Kesadaran terhadap hak perempuan dalam politik mulai dibangun melalui kebijakan penerapan affirmative action yang dituangkan dalam ketentuan peraturan perundang-undangan dengan angka minimal 30\% (tiga pulu perseratus) keterwakilan perempuan yang harus dicapai. Affirmative action bukanlah hal baru, sejak berlakunya Undang-Undang Nomor 12 Tahun 2003 tentang Pemilihan Umum hingga berlakunya undang-undang yang baru yaitu Undang-Undang Nomor 7 Tahun 2017 tentang Pemilihan Umum, hal tersebut yang masih menimbulkan pro dan kontra. Pasal 173 ayat (2) huruf e mengenai kuota $30 \%$ (tiga puluh perseratus) keterwakilan perempuan sebagai salah satu syarat wajib untuk menjadi peserta pada pemilu serentak 2019. Melalui Undang-Undang Nomor 7 Tahun 2017 diharapkan keterwakilan perempuan tercapai hingga 30\% (tiga puluh perseratus) dengan penguatan melalui kepengurusan partai politik tingkat pusat.
\end{abstract}

Kata Kunci: Partai Politik; Hak Asasi Perempuan; Partisipasi Politik Perempuan; Affirmative Action; Undang - Undang 7 Tahun 2017 Tentang Pemilihan Umum. 


\section{Pendahuluan}

Indonesia meratifikasi Konvensi mengenai Penghapusan Segala Bentuk Diskriminasi terhadap Perempuan (Convention on the Elimination of All Forms of Discrimination Againts Women) melalui Undang-undang Nomor 7 Tahun 1984. Ratifikasi ini menegaskan bahwa Pemerintah Indonesia berkomitmen pada dunia untuk menegakkan keadilan tanpa adanya diskriminasi dalam hal keseteraan gender. Hal ini juga menimbulkan semakin besarnya pengakuan Pemerintah Indonesia terhadap Hak Asasi Perempuan sebagai Hak Asasi Manusia.

Hak Asasi Manusia di Indonesia telah mengalami pasang-surut. Sesudah dua periode represi (rezim Soekarno 1945-1965 dan rezim Soeharto 1966-1998). Era reformasi yang dimulai sejak tahun 1999 berusaha lebih memajukan hak asasi manusia. Dalam kenyataannya, Pemerintah harus menghadapi tidak hanya pelanggaran hak secara vertical maupun horizontal. Pelaksanaan hak politik yang menjadi salah satu hal penting dalam kehidupan berdemokrasi di Indonesia relatif mengalami kemajuan. ${ }^{1}$ Keberadaan partai politik di Indonesia misalnya, menjadi ruang bagi masyarakat untuk mengekspresikan kebebasan dan keterbukaan dalam berdemokrasi. Masyarakat sebagai basis partai politik dan partai politik itu sendiri perlu saling komunikasi timbal balik. ${ }^{2}$ Partai Politik juga sebagai salah satu lembaga yang dapat menyalurkan ide-ide yang berimplikasi terhadap gender. Sebagai contoh misalnya, rekruitmen kepengurusan keterwakilan perempuan pada kepengurusan partai politik yang telah diatur dengan kuota $30 \%$ (persen) menurut peraturan perundang-undangan. ${ }^{3} \mathrm{Hal}$ ini berarti partai politik telah membuka peluang bagi perempuan untuk aktif dalam politik. Keterlibatan Perempuan ini dengan melihat kemampuan dan potensi dengan tidak membedakan status gender. Sebagaimana warga negara telah dijamin haknya yang telah diatur dalam Pasal 28 E ayat (3) UUD NRI 1945, menyatakan bahwa setiap orang berhak atas kebebasan berserikat, berkumpul, dan mengeluarkan pendapat.

\footnotetext{
${ }^{1}$ Miriam Budiardjo, Dasar-Dasar Ilmu Politik (Gramedia Pustaka Utama 1992).[247].

2 Ramly Hutabarat, 'Peranan Partai Politik Menyerap Aspirasi Masyarakat dan Hukum Politik Yang Tidak Semantik’ (2005) 35.3 Jurnal Hukum \& Pembangunan.[315].

${ }^{3}$ Undang-Undang Nomor 7 Tahun 2017 tentang Pemilihan Umum (Lembaran Negara Republik Indonesia Tahun 2017 Nomor 182_Tambahan Lembaran Negara Nomor 6109)
} 
HAM menurut Undang-Undang Nomor 39 Tahun 1999 tentang Hak Asasi Manusia yang selanjutnya disebut UU HAM adalah seperangkat hak yang melekat pada hakikat dan keberadaan manusia sebagai makhluk Tuhan Yang Maha Esa dan merupakan anugrah-Nya yang wajib dihormati, dijunjung tinggi dan dilindungi oleh negara hukum, pemerintah dan setiap harkat dan martabat manusia. ${ }^{4}$ Lebih lanjut ditegaskan dalam Pasal 3 UU HAM yang menyatakan bahwa:

(1) Setiap manusia dilahirkan bebas dengan harkat dan martabat manusia yang sama dan sederajat serta dikaruniai akal dan hati nurani untuk hidup bermasyarakat, berbangsa dan bernegara dalam semangat persaudaraan.

(2) Setiap orang berhak atas pengakuan dan jaminan perlindungan dan perlakuan hukum yang adil serta mendapat kepastian hukum dan perlakuan yang sama di depan hukum.

(3) Setiap orang berhak atas perlindungan hak asasi manusia dan kebebasan dasar manusia tanpa diskriminasi. ${ }^{5}$

Pemenuhan hak-hak juga mengalami berbagai tantangan termasuk untuk mewujudkan hak perempuan yang terkait dengan hak dalam ranah politik. Sejak reformasi, perempuan masih memperjuangkan hak-hak politiknya demi memutus kesenjangan yang terjadi di masyarakat Indonesia. Awal perempuan masuk ke ranah politik, perempuan hanya dapat menyalurkan hak politik mereka melalui pemberian suara dalam pemilihan umum. Keterwakilan perempuan dalam pemerintahan baik di lembaga eksekutif ataupun legislatif menjadi sangat penting. Perempuan mampu untuk memudahkan akses bagi persoalan perempuan dalam hal mengawasi dan menyuarakan kebijakan-kebijakan yang masih tidak adil bagi hak-hak perempuan. ${ }^{6}$

Di era Orde Baru, keterwakilan perempuan di parlemen juga mengalami pasang-surut. Pemilu pertama, era Orde Baru berhasil menempatkan perempuan pada di parlemen dengan jumlah perempuan yang tidak lebih dari 10 persen. $^{7}$ Selanjutnya, pada pemilu di era Reformasi sejak tahun 1999 hingga 2014 kembali

\footnotetext{
${ }^{4}$ Arbaiyah Prantiasih, 'Jurnal Pendidikan Pancasila dan Kewarganegaraan (2012).[11].

5 Undang-undang Nomor 39 Tahun 1999 tentang Hak Asasi Manusia (Lembaran Negara Nomor 165, Tambahan Lembaran Negara Nomor 3886).

6 Ufi Ulfiah, Perempuan di Panggung Politik (Rahima 2007).[19].

7 Ibid.
} 
menaikkan jumlah perempuan melalui tindakan afirmasi yang ditetapkan oleh Pemerintah dengan kuota $30 \%$ yang diatur berdasarkan peraturan perundangundangan. ${ }^{8}$ Namun, pada kenyataannya hal ini belum dapat menaikkan jumlah keterwakilan perempuan sesuai kuota yang telah diatur. Bahkan mengalami penurunan jumlah keterwakilan perempuan dari pemilu 2009 ke pemilu 2014.

Berdasarkan Undang-Undang Nomor 10 Tahun 2008 Tentang Pemilihan Umum pada pemilu 2009 dengan mempertegas pasal keterwakilan perempuan yang diatur dalam Pasal 52 dan Pasal 53 menyatakan bahwa:

Pasal 52

(1) Bakal calon sebagaimana dimaksud dalam Pasal 51 disusun dalam daftar bakal calon oleh partai politik masing-masing.

(2) Daftar bakal calon anggota DPR ditetapkan oleh pengurus Partai Politik Peserta Pemilu tingkat pusat.

(3) Daftar bakal calon anggota DPRD provinsi ditetapkan oleh pengurus Partai Politik Peserta Pemilu tingkat provinsi.

(4) Daftar bakal calon anggota DPRD kabupaten/kota ditetapkan oleh pengurus Partai Politik Peserta Pemilu tingkat kabupaten/kota.

\section{Pasal 53}

"Daftar bakal calon sebagaimana dimaksud dalam Pasal 52 memuat paling sedikit 30\% (tiga puluh perseratus) keterwakilan perempuan." Lebih lanjut Pasal diatas dipertegas dengan Pasal 55 ayat (2) yang berbunyi: "Di dalam daftar bakal calon sebagaimana dimaksud pada ayat (1), setiap 3 (tiga) orang bakal calon terdapat sekurang-kurangnya 1 (satu) orang perempuan bakal calon".

Kemudian, keterwakilan perempuan diperkuat pula melalui Undang-Undang Nomor 2 Tahun 2011 Tentang Perubahan Atas Undang-undang Nomor 2 Tahun 2008 Tentang Partai Politik menguatkan aturan mengenai keterwakilan perempuan untuk mendapat kesempatan di bidang politik khususnya kesempatan duduk di parlemen sebagaimana diatur dalam Pasal 2 ayat (2) bahwa pendirian dan pembentukan partai politik dengan menyertakan 30\% (tiga puluh perseratus) keterwakilan perempuan”.

Dari pasal-pasal di atas mempertegas bagaimana perempuan sangat diperhitungkan dalam kegiatan di bidang politik. Tindakan tersebut bertujuan

8 Herita Dewi, 'Perempuan dan Politik Dalam Perspektif Kesetaraan Gender' $2016<$ http:// www.sumbarprov.go.id/details/news/8277>, diakses pada tanggal 2 Oktober 2017. 
untuk mewujudkan keterwakilan perempuan demi tercapainya angka 30\% (tiga puluh perseratus) sebagaimana telah diatur dalam undang-undang sebelumnya. Keterwakilan perempuan ini juga harus diawali dengan adanya pengurus perempuan yang berkompeten di dalam kepengurusan partai politik. Hal ini sejalan dengan adanya undang-undang nomor 7 Tahun 2017 yang pengaturannya mempertegas kembali mengenai kuota perempuan untuk lebih terlibat aktif dalam kegiatan politik melalui kepengurusan partai politik.

Dengan berlakunya Undang-Undang Nomor 7 Tahun 2017 tentang Pemilihan Umum (Lembaran Negara Republik Indonesia Tahun 2017 Nomor 182, Tambahan Lembaran Negara Nomor 6109) dengan tetap memperhatikan kuota 30 persen keterwakilan perempuan dalam kepengurusan partai politik sebagai syarat administrasi yang wajib dipenuhi sebagai calon peserta pemilu. Karena pada undang-undang sebelumnya keterwakilan perempuan belum dapat memenuhi kuota 30 persen, sehingga keterwakilan perempuan lebih dipertegas kembali dengan adanya aturan mengenai keterwakilan perempuan dalam kepengurusan partai politik tingkat pusat untuk memenuhi persyaratan partai politik sebagai peserta pemilu sebagaimana diatur dalam Pasal 173 ayat (2) huruf e, yang menyatakan bahwa syarat untuk menjadi calon peserta pemilu partai politik dengan menyertakan paling sedikit 30\% (tiga puluh perseratus) keterwakilan perempuan pada kepengurusan partai politik tingkat pusat.

Hal ini menimbulkan pemikiran bahwa laki-laki masih dominan dalam kepemimpinan maka diperlukan penyeimbang sebagai pencapaian terhadap kesetaraan gender dalam konteks demokrasi yang dianggap tepat dalam bidang politik khususnya memperhatikan keterwakilan perempuan dalam kepengurusan partai politik yang diawali dari tingkat pusat dengan pemerataan rekruitmen di setiap cabang partai politik yang ada di daerah wilayah Indonesia.

Kemudian, Undang-Undang a quo juga mengatur bagaimana mengenai bakal calon peserta pemilu pada legislatif dengan tetap memperhatikan keterwakilan perempuan dalam Pasal 241, 243, dan 245 yang berbunyi: 
Pasal 241

(1) Partai Politik Peserta Pemilu melakukan seleksi bakal calon anggota DPR, DPRD provinsi, dan DPRD kabupaten/kota.

(2) Seleksi bakal calon sebagaimana dimaksud pada ayat (1) dilakukan secara demokratis dan terbuka sesuai dengan anggaran dasar, anggaran rumah tangga, dan/atau peraturan internal Partai Politik Peserta Pemilu.

Pasal 243

(1) Bakal calon sebagaimana dimaksud dalam Pasal 241 disusun dalam daftar bakal calon oleh partai politik masing-masing.

(2) Daftar bakal calon anggota DPR ditetapkan oleh pengurus Partai Politik Peserta Pemilu tingkat pusat

(3) Daftar bakal calon anggota DPRD provinsi ditetapkan oleh pengurus Partai Politik Peserta Pemilu tingkat provinsi.

(4) Daftar bakal calon anggota DPRD kabupaten/kota ditetapkan oleh pengurus Partai Politik Peserta Pemilu tingkat kabupaten/kota.

Pasal 245

"Daftar bakal calon sebagaimana dimaksud dalam Pasal 243 memuat keterwakilan perempuan paling sedikit 30\% (tiga puluh persen)."

Berdasarkan bunyi pasal diatas, Partai Solidaritas Indonesia (PSI), Partai Islam dan Damai (IDAMAN) dan Partai Persatuan Indonesia (PERINDO) mengajukan permohonan judicial review ke Mahkamah Konstitusi terkait keterwakilan perempuan dalam kepengurusan partai politik tingkat pusat. Bahwa dalam Pasal 173 ayat (2) huruf e dinilai tidak sejalan dengan Pasal 245 pada undang-undang yang sama. Dan partai memiliki kewajiban mengalokasikan kursi calon legislatifnya terhadap keterwakilan perempuan sebanyak 30 persen.

Dengan minimnya jumlah perempuan di kepengurusan partai politik, upaya untuk memenuhi kuota tersebut akan sangat sulit untuk diterapkan. Ketua umum Partai Solidaritas Indonesia (PSI) menambahkan bahwa selama ini partai politik mengaku kesulitan menjaring perempuan ke kursi calon legislatif khususnya pada Partai Politik berstatus baru. Tidak sedikit yang terpaksa mengusung calon boneka hanya untuk memenuhi administratif saja. ${ }^{9}$

9 Miftahul Hayat, 'Keterwakilan Perempuan Digugat' (2017) Jawa Pos. [2]. 
Berdasarkan latar belakang diatas, letak permasalahan yang menjadi penelitian akan diuraikan dalam pernyataan sebagai berikut: Untuk mengkaji dan meneliti mengenai kajian normatif keterwakilan perempuan dalam sistem politik. Memecahkan permasalahan dengan penguatan keterwakilan perempuan dalam sistem pemilu melalui kepemimpinan perempuan di partai politik. Sumber data yang digunakan dalam penelitian ini adalah sumber bahan hukum primer berupa peraturan perundang-undangan dan bahan hukum sekunder berupa jurnal hukum dan buku-buku tentang keterwakilan perempuan dalam politik.

Dalam penelitian ini, maka yang akan digunakan adalah tipe penelitian yuridis normatif. Pendekatan yang dipergunakan yaitu pendekatan historis (historical approach), pendekatan perundang-undangan (statute approach), dan pendekatan konsep (conceptual approach), yang diambil dari beberapa sumber bahan hukum.

\section{Hak Asasi Perempuan dalam Politik}

Pembahasan mengenai keterwakilan perempuan tentunya tidak terlepas dari ranah politik yang makin memberikan peluang besar untuk demokrasi di Indonesia. Keterwakilan perempuan menjadi penting dengan memberi peluang bagi perempuan memperjuangkan kepentingan mereka. Perjuangan perempuan di wilayah publik adalah sebuah proses panjang. Kongres Wanita Indonesia pertama, pada 22-25 Desember tahun 1928 membangkitkan kesadaran dan meningkatkan rasa nasionalisme di kalangan perempuan. Hal tersebut merupakan tonggak sejarah, karena berperan dalam meningkatkan kesempatan bagi perempuan Indonesia untuk berpartisipasi dalam pembangunan, termasuk dalam politik. ${ }^{10}$

Hasil dari kesepakatan dalam Kongres Perempuan Indonesia I di atas merupakan cerminan terhadap tekad kaum perempuan dalam mewujudkan dan mendukung persatuan Indonesia dengan dibentuknya federasi perkumpulan

10 Khofifah Indar Parawansa, 'Studi Kasus: Hambatan Partisipasi Politik di Indonesia' <https://s3.amazonaws.com/academia.edu.documents/37076367/BAHAN_MATERI_.pdf?AWSAccessKeyId=AKIAIWOWYYGZ2Y53UL3A\&Expires $=1507001954 \&$ Signature $=$ ckZ52us587sUTUgy96c Yug F4UA8 \%3 D\&response-content disposition=inline\%3B\% 20filename\%3D Hambatan_terhadap_Partisipasi_Politik. pdf $>$ diakses pada tanggal 3 Oktober 2017. 
wanita yaitu Persatuan Perempuan Indonesia (PPI). Sejak terbentuknya persatuan tersebut PPI memusatkan tugasnya untuk memperhatikan pendidikan dan upaya penghapusan perdagangan perempuan. ${ }^{11}$ Hal tersebut, merupakan cerminan dalam penegakan hak asasi perempuan.

Hak Asasi Perempuan dalam politik merupakan bagian penting. Pertama, bahwa hak asasi perempuan dimaksudkan kepada pengakuan perempuan sebagai manusia yang berdampak terhadap perlindungan hak-hak dasar. Kedua, hak asasi perempuan mempunyai tujuan dan maksud gender. Makna Hak Asasi Perempuan kedua ini lebih revolusioner karena adanya pengintegrasian Hak Asasi Perempuan dalam standar Hak Asasi Manusia (HAM). ${ }^{12}$

Keinginan untuk merumuskan hak asasi manusia yang diakui oleh seluruh dunia pun dituangkan dalam Universal Declaration of Human Rights, dan dapat diterima oleh 48 negara hasil dari pekerjaan Komisi HAM (Commission on Human Rights). Deklarasi Universal Hak Asasi Manusia dimaksudkan sebagai pedoman sekaligus standar minimun cita-cita seluruh umat manusia. ${ }^{13}$

Deklarasi Universal Hak Asasi Manusia yang disahkan oleh Majelis Umum Perserikatan Bangsa-Bangsa pada 10 Desember 1948 merupakan Deklarasi yang dikodifikasi dengan memperhatikan pengakuan HAM yang di dalamnya termasuk hak asasi perempuan. Deklarasi menjadi pedoman bagi bangsa-bangsa yang mengakui dan masyarakat Internasional untuk melindungi martabat manusia. Dan beberapa hak yang diatur dalam DUHAM adalah kebebasan berekspresi dan partisipasi politik tanpa adanya perbedaan gender.

Berdasarkan Pasal 29 DUHAM, yang menyatakan bahwa setiap orang mempunyai kewajiban terhadap masyarakatnya dan bahwa dalam pelaksanaan hakhak dan kekuasaannya setiap orang hanya dapat dibatasi oleh hukum yang sematamata untuk menjamin pengakuan serta penghormatan yang layak atas hak-hak dan kebebasan-kebebasan orang lain, dalam rangka memenuhi persyaratan-persyaratan

\footnotetext{
${ }^{11}$ Kementerian Pemberdayaan Perempuan dan Perlindungan Anak, Op.cit., [14].

${ }_{12}$ Miriam Budiardjo, Op.Cit. [256-257].

${ }^{13}$ Ibid.[218-219].
} 
yang adil dalam moralitas, kesusilaan ketertiban umum, dan kesejahteraan umum yang adil dalam masyarakat demokratis..$^{14}$ Berdasarkan pernyataan tersebut dapat dikatakan bahwa tidak adanya bentuk diskriminsi apapun termasuk pembedaan antara hak perempuan maupun laki-laki, karena pada dasarnya manusia memiliki hak yang sama.

Indonesia telah meratifikasi perjanjian Internasional seperti, Hak Sipil dan Politik Internasional, Hak Ekonomi, Sosial dan Budaya Internasional serta Konvensi mengenai Penghapusan Segala Bentuk Diskriminasi terhadap Perempuan dengan menjamin hak - hak warga negaranya untuk tidak melakukan diskriminasi dalam bentuk apapun kepada setiap warga negara baik laki-laki maupun perempuan. Dari kedua perjanjian Hak Sipil dan Politik Internasional, Hak Ekonomi, Sosial dan Budaya Internasional telah diratifikasi Indonesia dengan dibentuknya UndangUndang Nomor 11 tahun 2005 dan Undang-Undang Nomor 12 tahun 2005 sebagaimana dituangkan dalam pasal-pasal, sebagai berikut:

\section{Kovenan Hak-hak Sipil dan Politik}

Pasal 2 ayat (1)

"Setiap negara pihak pada Kovenan ini berjanji untuk menghormati dan menjamin hak-hak yang diakui dalam Kovenan ini bagi semua orang yang berada dalam wilayah hukumnya, tanpa pembedaan apapun seperti ras, warna kulit, jenis kelamin, agama, politik atau pendapat lain, asal-usul kebangsaan atau sosial, kekayaan, kelahiran atau status lainya."

Pasal 26.

"Semua orang adalah sama terhadap hukum dan berhak atas perlindungan hukum yang sama tanpa diskriminasi. Dalam hubungan ini, hukum melarang setiap diskriminasi serta menjamin semua orang akan perlindungan yang sama dan efektif terhadap diskriminasi atas dasar apapun seperti ras, warna kulit, kelamin, bahasa, agama, pendapat politik atau pendapat lain, bangsa asal atau kedudukan sosial-asal, milik, kelahiran atau kedudukan lainnya.

\section{Kovenan Hak-hak Ekonomi, Sosial, dan Budaya}

Pasal 2 ayat (2)

\footnotetext{
${ }^{14}$ Universal Declaration of Human Rights 1948 (Deklarasi Universal Hak Asasi Manusia).
} 
"Setiap negara peserta Kovenan ini berusaha untuk menjamin, bahwa hakhak yang terjamin dalam Kovenan ini akan dilaksanakan tanpa diskriminasi apapun misalnya mengenai ras, jenis kelamin, bahasa, agama, pendapat politik atau pendapat yang lain, asal-usul kebangsaan atas sosial, kekayaan, kelahiran atau status lain.”

Mengenai prinsip non diskriminasi terhadap perempuan diatur lebih lanjut dalam Pasal 3 dengan menyatakan bahwa: "Negara Pihak Kovenan ini berjanji untuk menjamin hak-hak yang sederajat dari laki-laki dan perempuan untuk menikmati hak sipil dan politik yang diatur dalam Kovenan ini”.

Untuk merealisasikan hak perempuan butuh upaya untuk meningkatkan keterwakilan perempuan. Partai politik adalah kunci partisipasi politik perempuan, karena mulai dari partai yang merekrut hingga memilih calon untuk ikut serta dalam agenda pemilihan umum.

\section{Partai Politik dan Perempuan}

Partai politik merupakan salah satu sarana bagi masyarakat untuk menyalurkan partisipasi dan aspirasi dalam proses bernegara. Dewasa ini partai politik tidak lagi asing di lingkungan masyarakat. ${ }^{15}$ Bahkan masyarakat tidak lagi segan untuk berproses dan terlibat dalam kegiatan-kegiatan politik karena keberadaannya sebagai organisasi yang cukup tua dalam perkembangan bangsa. Perjalanan sejarah partai politik di Indonesia mengalami berbagai perjuangan panjang dari masa ke masa.

Secara historis, partai politik berawal dari anggapan bahwa kelompok terorganisir yang anggota-anggotanya mempunyai orientasi, nilai dan cita-cita yang sama. ${ }^{16}$ Dalam menjalankan fungsinya partai politik sering disebut sebagai perantara dalam bursa ide-ide bagi pemerintah sebagai alat pendengar, sedangkan rakyat sebagai pengeras suara. ${ }^{17}$

Perjuangan partai politikjuga berdampak pada adanya keterwakilan perempuan dalam kepengurusan partai politik. Ada beberapa tokoh perempuan yang berperan

\footnotetext{
${ }^{15}$ Miriam Budiardjo, Op.Cit., [397].

${ }^{16}$ Ibid. [403-404].

${ }^{17}$ Ibid. [406].
} 
dalam partai politik dan masih menonjol hingga saat ini. Khofifah Indar Parawansa, adalah kader dari Partai Politik yang aktif berkarir di dunia pemerintahan. Adapun karir politiknya sebagai:

(1) Pimpinan Fraksi Partai Persatuan Pembangunan DPR RI (1992 - 1997);

(2) Pimpinan Komisi VIII DPR RI (1995 - 1997);

(3) Anggota Komisi II DPR RI (1997 - 1999);

(4) Wakil Ketua DPR RI (1999);

(5) Sekretaris Fraksi Partai Kebangkitan Bangsa MPR RI (1999);

(6) Menteri Negara Pemberdayaan Perempuan (1999 - 2001);

(7) Kepala Badan Koordinasi Keluarga Berencana Nasional (1999 - 2001);

(8) Ketua Komisi VII DPR RI (2004 - 2006);

(9) Ketua Fraksi Kebangkitan Bangsa MPR RI (2004 - 2006); (10) Anggota Komisi VII DPR RI (2006);

(10) Menteri Kabinet Sosial Kerja (2014-sekarang). ${ }^{18}$

Undang-Undang Partai Politik hadir untuk mengakomodir kepastian hukum pergerakan yang ada dalam organisasi politik. Sebagaimana diatur dalam Pasal 1 angka 1 Undang - Undang Nomor 2 Tahun 2011 tentang Perubahan atas Undang Undang Nomor 2 Tahun 2008 tentang Partai Politik yang dimaksud Partai politik adalah organisasi yang bersifat nasional dan dibentuk oleh sekelompok warga negara Indonesia secara sukarela atas dasar kesamaan kehendak dan cita-cita untuk memperjuangkan dan membela kepentingan politik anggota, masyarakat, bangsa dan negara, serta memelihara keutuhan Negara Kesatuan Indonesia Republik Indonesia berdasarkan Pancasila dan Undang-undang Dasar Negara Republik Indonesia Tahun 1945. ${ }^{19}$

Berdasarkan perbandingan yang ada dalam Undang-Undang Nomor 2 Tahun 2008 tentang Partai Politik dan Undang-Undang Nomor 2 Tahun 2011 tentang Perubahan Atas Undang-Undang Nomor 2 Tahun 2008 tentang Partai Politik dapat dilihat pada Tabel berikut:

18 Rizka Damayanti, 'Profil dan Biografi Khofifah Indar Parawansa' <http://www.profilpedia.com/2014/12/profil-dan-biografi-khofifah-indar-parawansa.html $>$, diakses pada tanggal 8 Januari 2018.

${ }_{19}$ Undang-undang Nomor 2 Tahun 2011 Tentang Perubahan atas Undang-undang Nomor 2 Tahun 2008 Tentang Partai Politik. 
Tabel 1: Perbandingan 2 Undang-Undang Partai Politik tentang Keterwakilan Perempuan

\begin{tabular}{|c|c|}
\hline $\begin{array}{c}\text { UU Nomor } 2 \text { Tahun } 2008 \text { tentang Partai } \\
\text { Politik }\end{array}$ & $\begin{array}{c}\text { UU Nomor } 2 \text { Tahun } 2011 \text { tentang Partai } \\
\text { Politik }\end{array}$ \\
\hline $\begin{array}{l}\text { Pasal } 2 \\
\text { (2) Pendirian dan pembentukan Partai } \\
\text { Politik sebagaimana dimaksud pada ayat (1) } \\
\text { menyertakan 30\% (tiga puluh perseratus) } \\
\text { keterwakilan perempuan. } \\
\text { (5) Kepengurusan Partai Politik tingkat } \\
\text { pusat sebagaimana dimaksud pada ayat (2) } \\
\text { disusun dengan menyertakan paling rendah } \\
\text { 30\% (tiga puluh per seratus) keterwakilan } \\
\text { perempuan. }\end{array}$ & $\begin{array}{l}\text { Pasal } 2 \\
\text { (2) Pendirian dan pembentukan Partai Poli- } \\
\text { tik sebagaimana dimaksud pada ayat (1) } \\
\text { menyertakan } \mathbf{3 0 \%} \text { (tiga puluh per sera- } \\
\text { tus) keterwakilan perempuan. } \\
\text { (5) Kepengurusan Partai Politik tingkat pusat } \\
\text { sebagaimana dimaksud pada ayat (2) disusun } \\
\text { dengan menyertakan paling sedikit } \mathbf{3 0 \%} \\
\text { (tiga puluh per seratus) keterwakilan } \\
\text { perempuan." }\end{array}$ \\
\hline $\begin{array}{l}\text { Pasal } 20 \\
\text { Kepengurusan Partai Politik tingkat } \\
\text { provinsi dan kabupaten/kota sebagaimana } \\
\text { dimaksud dalam Pasal } 19 \text { ayat (2) dan } \\
\text { ayat (3) disusun dengan memperhatikan } \\
\text { keterwakilan perempuan paling rendah } 30 \% \\
\text { (tiga puluh perseratus) yang diatur dalam } \\
\text { AD dan ART Partai Politik masing-masing. }\end{array}$ & $\begin{array}{l}\text { Pasal } 29 \text { ayat (1a) yang menyatakan bahwa: } \\
\text { Rekrutmen sebagaimana dimaksud pada } \\
\text { ayat (1) huruf b dilaksanakan melalui seleksi } \\
\text { kaderisasi secara demokratis sesuai dengan } \\
\text { AD dan ART dengan mempertimbangkan } \\
\text { paling sedikit } 30 \% \text { (tiga puluh per seratus) } \\
\text { keterwakilan perempuan. }\end{array}$ \\
\hline
\end{tabular}

Berdasarkan uraian tabel di atas pasal tersebut bahwa terjadi perubahan dalam frasa penormaan mengenai keterwakilan perempuan pada Undang-Undang Nomor 2 Tahun 2008 dan Undang-Undang Nomor 2 Tahun 2011 tentang Partai Politik. Terkait dengan keterwakilan perempuan dalam partai politik, perubahan terjadi antara Pasal 20 Undang-Undang Nomor 2 Tahun 2008 dan Pasal 29 ayat (1a) Undang-Undang Nomor 2 Tahun 2011 yang menegaskan lebih lanjut mengenai aturan rekrutmen yang dilaksanakan dengan melalui tahap kaderisasi terlebih dahulu sebelum menjadi pengurus partai politik dengan memperhatikan AD/ART partai politik mengenai rekrutmen keterwakilan perempuan paling sedikit 30\% (tiga puluh perseratus).

Demikian pada pernyataan diatas seharusnya dapat menjadikan partai politik sebuah sarana bagi pemenuhan kepentingan rakyat. Karena pada dasarnya partaipartai politik telah melembagakan ide-ide mengenai politik yang juga mempunyai 
implikasi gender. Dalam sistem pemerintahan partai yang mewarnai begitu banyak negara demokratis, tugas menyamakan perwakilan laki-laki dan perempuan harus mulai dalam partai politik. ${ }^{20}$

\section{Penerapan Affirmative Action}

Affirmative action (tindakan afirmatif) merupakan suatu kebijakan yang bertujuan agar kelompok/golongan tertentu (gender ataupun profesi) memperoleh peluang yang setara dengan kelompok/golongan lain dalam bidang yang sama. ${ }^{21}$ Affirmative action bertujuan untuk menekan tindakan diskriminasi dalam suatu masyarakat dengan begitu dipertegas pula dalam Pasal 4 ayat (1) CEDAW:

"Kebijakan khusus yang dijalankan para negara anggota yang ditujukan pada peningkatan persamaan de facto antara laki-laki dan perempuan tidak akan dianggap sebagai diskriminasi seperti yang didefinisakan konvensi ini, tetapi dalam cara apa pun tidak dapat dianggap sebagai konsekuensi dipertahankannya standar yang tidak sama atau terpisah; tindakan ini tidak akan dilanjutkan apabila tujuan persamaan kesempatan dan perlakuan telah tercapai”.

Selanjutnya, keterwakilan perempuan sejak munculnya affirmative action sebagai langkah awal untuk mendongkrak keterwakilan perempuan dalam keikutsertaannya di kepungurusan partai politik hingga pemilihan umum telah dituangkan dalam peraturan perundang-undangan berikut:

a. UU Nomor 12 Tahun 2003 Tentang Pemilihan Umum;

b. UU Nomor 2 Tahun 2008 Tentang Partai Politik;

c. UU Nomor 2 Tahun 2011 Tentang Perubahan Atas UU Nomor 2 Tahun 2008 Tentang Partai Politik;

d. UU Nomor 15 Tahun 2011 Tentang Penyelenggaraan Pemilu;

e. UU Nomor 8 Tahun 2012 Tentang Pemilihan Umum Anggota DPR, DPD, dan DPRD;

f. UU Nomor 7 Tahun 2017 Tentang Pemilihan Umum.

Pada dasarnya, politik hukum dalam peraturan perundang-undangan di atas yang telah disebutkan. Substansi mengenai keterwakilan perempuan tetap sama yaitu dengan kuota 30 persen. Namun, ketentuan mengenai affirmative action

${ }^{20}$ Joni Lovenduski, Politik Berparas Perempuan (Kanisius 2008).[107].

${ }^{21}$ Affirmative action, $2009<$ http://www.hukumonline.com/klinik/detail/cl6904/affirmative-action>, diakses pada tanggal 25 Oktober 2017. 
secara eksplisit belum diatur menyeluruh oleh peraturan yang sudah ada dan berlaku hingga keluar undang-undang yang baru.

\section{Penguatan Keterwakilan Perempuan dalam Undang-Undang Nomor 7 Tahun 2017 Tentang Pemilihan Umum}

Dengan penguatan dalam Undang - undang partai politik pada pembahasan sebelumnya, nyatanya belum dapat meningkatkan peran perempuan dalam keterlibatan baik kepengurusan partai politik secara menyeluruh maupun pengisian jabatan di Parlemen. Hingga upaya lain dilakukan oleh permerintah pada baru baru ini di Tahun 2017 dengan mempertegas kembali di Undang-undang Nomor 7 Tahun 2017 Tentang Pemilihan Umum. Dimana dalam UU Nomor 7 Tahun 2017 tersebut pemilu legislatif akan serentak dilaksanakan dengan pemilihan presiden pada 2019 mendatang.

Ada politik hukum dalam setiap perubahan undang-undang pemilu menjelang musim pemilihan umum setiap 5 tahun sekali. Yaitu, di setiap perubahan undangundang pemilu dari Undang-Undang Nomor 10 tahun 2008 hingga Undang-Undang Nomor 7 Tahun 2017 perubahan undang-undang pemilu tidak mengalami hal yang signifikan justru stagnan di Undang-Undang Nomor 7 Tahun 2017 dengan tetap mengatur paling sedikit keterwakilan perempuan dengan kuota $30 \%$ begitu pula dengan daftar bakal calon legislative yang hamper sama dengan ketentuan dalam pasal-pasal Undang-Undang sebelumnya yaitu Undang-Undang Nomor 8 Tahun 2012. Melihat trend anggota legislative dari 3 periode pemilu 2004-2014, perolehan suara parlemen pada kursi keterwakilan perempuan mengalami penurunan pada pemilu 2014 lalu dengan presentase 17,32\% dibandingkan pada pemilu 2009 sebelumnya yang memperoleh kursi sebanyak 18\%. Namun sayangnya, tidak membawa perubahan meski undang-undangnya telah diubah. Oleh karena itu, dibutuhkan kesungguhan dari partai politik untuk menguatkan keterwakilan perempuan demi mememuhi kuota 30 persen dengan mengatur dalam AD/ART partai politik. Hal ini menjadi penting karena partai politik mempunyai peran utama dalam meningkatkan partisipasi dan keterwakilan perempuan di tingkat pusat 
sebagai syarat utama memenuhi ketentuan dalam Pasal 173 ayat (2) huruf e UU a quo. Dengan demikian, partai politik akan lebih siap dan matang sebagai wadah organisasi bagi kendaraan utama yang tidak hanya mengedapankan kuantitas kader perempuan akan tetapi juga kualitas untuk menjalankan perannya dalam bidang politik. Hal ini dapat diterapkan pula ke tingkat daerah baik provinsi, kabupaten/ kota maupun kecamatan. Sebagai bukti beberapa partai politik lama dan partai politik baru yang telah menerapkan sistem kuota dalam rekruitmen kepengurusan terutaman bagi calon pengurus perempuan.

\section{Kesimpulan}

Jaminan atas perlindungan dan pemenuhan hak terhadap keterwakilan perempuan di kepengurusan partai politik telah ada sebagaimana tertuang dalam UUD NRI 1945 sebagai konstitusi negara, dan secara normatif diatur dalam perjanjian Internasional dan peraturan perundang-undangan seperti, DUHAM, CEDAW, UU HAM, UU Hak Sipil Politik, Hak Ekosob, UU Partai Politik, dan UU Pemilihan Umum. Bahwa untuk mewujudkan keterwakilan perempuan diterapkanlah pemenuhan kuota 30 persen dalam pengisian pengurus partai politik, meski belum dapat dipenuhi secara menyeluruh namun hingga saat ini partai politik diharuskan untuk meningkatkan keterwakilan perempuan pertama-tama melalui rekrutmen kepengurusan partai politik.

Undang-undang pemilu telah mengalami beberapa kali perubahan sejak diberlakukannya Undang-Undang Nomor 10 Tahun 2008 dan diubah kembali dalam Undang-Undang Nomor 8 Tahun 2012, hingga perubahan ketiga dalam UndangUndang Nomor 7 Tahun 2017. Perubahan undang-undang tentang pemilu tersebut tetap konsisten mengakomodir affirmative action berupa kuota 30\% keterwakilan perempuan di parlemen, meski tiap undang-undang menggunakan pendekatan berbeda dalam memastikan ketercapaian kuota tersebut. Penggunaan frasa 'sekurang-kurangnya' pada kuota 30\% yang kemudian diubah dalam undang-undang tentang pemilu yang terbaru menjadi 'paling sedikit' sesungguhnya menunjukkan perkembangan positif dari upaya pelibatan perempuan di parlemen melalui affirmative 
action. Pemilihan frasa tersebut menunjukkan keyakinan bahwa prosentase keterlibatan perempuan semakin meningkat. Tidak hanya itu, undang-undang tentang pemilu juga memberikan ketentuan mengenai kepengurusan perempuan di tingkat pusat bagi partai politik sebagai prasyarat mengikuti pemilu. Ini menunjukkan bahwa secara normatif, peraturan perundang-undangan memberikan ruang sehingga target keterlibatan perempuan yang dikatakan paling sedikit 30\% tersebut lebih mungkin dicapai dengan sistem yang dibangun melalui undang-undang tentang pemilu yang baru dibandingkan dengan rezim undang-undang sebelumnya.

\section{Daftar Bacaan}

\section{Buku}

Miriam Budiardjo, Dasar-Dasar Ilmu Politik (Gramedia Pustaka Utama 1992).

Ufi Ulfiah, Perempuan di Panggung Politik (Rahima 2007)

Joni Lovenduski, Politik Berparas Perempuan (Kanisius 2008).

\section{Jurnal}

Ramly Hutabarat, 'Peranan Partai Politik Menyerap Aspirasi Masyarakat dan Hukum Politik Yang Tidak Semantik’ (2005) 35.3 Jurnal Hukum \& Pembangunan.

Arbaiyah Prantiasih, 'Jurnal Pendidikan Pancasila dan Kewarganegaraan', (2012).

\section{Laman}

Affirmative action, 2009 <http: // www. hukumonline.com/ klinik/ detail/ cl6904/ affirmative-action>.

Herita Dewi, 'Perempuan dan Politik Dalam Perspektif Kesetaraan Gender' 2016 $<$ http://www.sumbarprov.go.id/details/news/8277>

Khofifah Indar Parawansa, 'Studi Kasus : Hambatan Partisipasi Politik di Indonesia'<https://s3.amazonaws.com/academia.edu.documents/37076367/BAHAN_MATERI_.pdf?AWSAccessKeyId=AKIAIWOWYYGZ2Y53UL3A\&Expires $=1507001954 \&$ Signature $=$ ckZ52us587sUTUgy96cYugF4UA8\% 3D\&response-content disposition $=$ inline $\%$ 3B\%20filename $\% 3$ D Hambatan_terhadap_Partisipasi_Politik.pdf $>$.

Rizka Damayanti, 'Profil dan Biografi Khofifah Indar Parawansa' <http:// www. 
profilpedia.com/ 2014/ 12/ profil- dan- biografi- khofifah- indar-parawansa. html>.

\section{Perundang-undangan}

Universal Declaration of Human Rights 1948 (Deklarasi Universal Hak Asasi Manusia).

Convention on the Political Rights of Women 1953 (Konvensi Hak-hak Politik Kaum Wanita).

International Covenant on Civil and Political Rights 1966 (Konvenan Hak Sipil dan Politik).

International Covenant on Economic, Social, and Cultural Rights 1966 (Konvenan Hak Ekonomi, Sosial dan Budaya).

Convention on the Elimination of Discrimination Against Women 1979 (Konvensi Penghapusan Segala Bentuk Diskriminasi Terhadap Wanita).

Undang-Undang Dasar Sementara Tahun 1950.

Undang-Undang Dasar Negara Republik Indonesia Tahun 1945.

Undang-Undang Nomor 68 Tahun 1958 tentang Pengesahan Konvensi Hak-hak Politik Kaum Wanita (Lembaran Negara dan Tambahan Lembaran Negara Tahun1958).

Undang-Undang Nomor 7 Tahun 1984 tentang Pengesahan Konvensi Segala Bentuk Diskriminasi Terhadap Wanita Kaum Wanita(Lembaran Negara Republik Indonesia Tahun 1984 Nomor 29, 10Tambahan Lembaran Negara Republik Indonesia Nomor 3277).

Undang -Undang Nomor 2 Tahun 1999 tentang Partai Politik (Lembaran Negara Republik Indonesia Tahun 1999 Nomor 2, Tambahan Lembaran Negara Republik Indonesia Nomor 3809).

Undang-Undang No. 3 Tahun 1999 tentang Pemilihan Umum (Lembaran Negara Republik Indonesia Tahun 1999 Nomor 23, Tambahan Lembaran Negara Republik Indonesia Nomor 3810).

Undang-Undang No. 39 Tahun 1999 tentang Hak Asasi Manusia (Lembaran Negara Republik Indonesia Tahun 1999 Nomor 165, Tambahan Lembaran Negara Republik Indonesia Nomor 3886). 
Undang-Undang No. 31 Tahun 2002 tentang Partai Politik (Lembaran Negara Republik Indonesia Tahun 2002 Nomor 138, Tambahan Lembaran Negara Republik Indonesia Nomor 4251).

Undang-Undang No.12 Tahun 2003 tentang Pemilihan Umum Anggota Dewan Perwakilan Rakyat, Dewan Perwakilan Daerah, dan Dewan Perwakilan Rakyat Daerah (Lembaran Negara Republik Indonesia Tahun 2003 Nomor 37).

Undang-Undang No. 12 Tahun 2005 tentang Pengesahan International Convenant on Civil and Political Rights (Konvenan Internasional tentang Hak-Hak Sipil dan Politik), (Lembaran Negara Republik Indonesia Tahun 2005 Nomor 119, Tambahan Lembaran Negara Republik Indonesia Nomor 4558).

Undang-Undang Nomor 11 Tahun 2005 tentang Pengesahan International Covenant on Economic, Social and Cultural (Kovenan Internasional tentang Hak-hak Ekonomi, Sosial dan Budaya), (Lembaran Negara Republik Indonesia Tahun 2005 Nomor 118, Tambahan Lembaran Negara Republik Indonesia Tahun 2005 Nomor 4557).

Undang-Undang No. 2 Tahun 2008 tentang Partai Politik (Lembaran Negara Republik Indonesia Tahun 2008 Nomor 2, Tambahan Lembaran Negara Republik Indonesia Nomor 4801).

Undang-Undang No. 10 Tahun 2008 tentang Pemilihan Umum Anggota Dewan Perwakilan Rakyat, Dewan Perwakilan Daerah, dan Dewan Perwakilan Rakyat Daerah (Lembaran Negara Republik Indonesia Tahun 2008 Nomor 51, Tambahan Lembaran Negara Republik Indonesia Nomor 4836).

Undang-Undang Republik Indonesia Nomor 2 Tahun 2011 tentang Perubahan Atas Undang-Undang Nomor 2 Tahun 2008 Tentang Partai Politik.

Undang-Undang No. 8 Tahun 2012 tentang Pemilihan Umum Anggota Dewan Perwakilan Rakyat, Dewan Perwakilan Daerah, dan Dewan Perwakilan Rakyat Daerah (Lembaran Negara Republik Indonesia Tahun 2011 Nomor 8, Tambahan Lembaran Negara Republik Indonesia Nomor 5189).

Undang-undang Nomor 7 Tahun 2017 tentang Pemilihan Umum (Lembaran Negara Republik Indonesia Tahun 2017 Nomor 182, Tambahan Lembaran Negara Republik Indonesia Nomor 6109).

\section{Surat Kabar}

Miftahul Hayat, 'Keterwakilan Perempuan Digugat' (2017) Jawa Pos. 